\title{
THE TROJAN ASS: ASINARIUS AS MOCK EPIC
}

\author{
Stijn Praet
}

\begin{abstract}
The medieval narrative poem Asinarius (late 12th-early 13th c.) has commonly been considered a fairy tale ante litteram, predating the self-conscious development of the literary genre from early modern times onward. Under influence of the deeply rooted notion that fairy tales have their origins in oral-folkloric traditions, scholars who have studied this text have tended to do so in terms of its supposed indebtedness to folktales, possibly even derived from Indian mythology. Meanwhile, its essential nature as a piece of Latin literature has been largely neglected. This article proposes a literary contextualizing of the text, situating it within the broader field of Latin literature. More specifically, it argues that the Asinarius poet playfully engages with epic texts, both ancient and contemporary, dealing with the matter of Troy. Thus, the reader is invited to a mock-epic reading of the poem, all too easily obfuscated today by an anachronistic "Grimmian" perspective.

Keywords: Asinarius, Das Eselein, fairy tale, Latin elegiac comedy, medieval parody, mock epic, matter of Troy, Simon Aurea Capra, Paris, Neoptolemus.
\end{abstract}

\section{INTRODUCTION}

For 200 years, ever since the Brothers Grimm published the first edition of their Kinder- und Hausmärchen (1812-1857), there has existed a powerful association in the minds of scholars and the broader public alike between folk and fairy tales. Accordingly, much of the scholarly attention up until the late seventies of last century was shaped by this association. Then in the past few decades, a shift occurred in the field of fairy-tale studies, awarding an increasingly important position to the literary aspects of the genre. Whereas fairy tales were once commonly treated as (contaminated) crystallizations of a longstanding national and/or international oral tradition of folktales, scholars like Ute Heidmann and Jean-Michel Adam now argue that

l'analyse de n'importe quel conte est bloquée par le renvoi systématique au folklore et aux "contes-types." Le fait de considérer Basile, Perrault, Marie-Jeanne Lhéritier ou Marie-Catherine d'Aulnoy comme les transcripteurs de contes populaires a empêché les découvertes que l'on peut faire quand on replonge leurs recueils dans le cadre socio-discursif de leur émergence historique et quand on prend au sérieux leur nature de textes. ${ }^{1}$

While the literary (re-)contextualization of fairy-tale texts has gained success in recent years, ${ }^{2}$ there are several areas in the field that have yet to benefit from this approach, among which that of the medieval Latin "fairy tale." I insert quotation marks here,

\footnotetext{
"Department of Literary Studies (Latin), Ghent University, Blandijnberg 2, B-9000 Ghent, Belgium.

1 "The analysis of any given tale is blocked by the systematic resorting to folklore and 'tale types.' Considering [the fairy tale authors] Basile, Perrault, Marie-Jeanne Lhéritier or Marie-Catherine d'Aulnoy as the transcribers of popular tales has impeded the kind of discoveries that could be made by reimmersing their collections in the socio-discursive context of their historical emergence and by taking seriously their nature as texts." Ute Heidmann and Jean-Michel Adam, Textualité et intertextualité des contes: Perrault, Apulée, La Fontaine, Lhéritier (Paris 2010) 20.

${ }^{2}$ Nonetheless, the scholarly field today is far from unified when it comes to the degree of indebtedness of fairy tales to folklore versus the individual creative efforts of literary authors; the debate is waged quite fiercely from both sides. For two brief conflicting historical surveys of the development of the fairy-tale genre, see Ruth Bottigheimer, Fairy Tales: A New History (New York 2009); and Jack Zipes, When Dreams Came True: Classical Fairy Tales and Their Tradition (London/New York 2007) 1-32. For the debate itself, see Jack Zipes, The Irresistible Fairy Tale: The Cultural and Social History of a Genre (Oxford/Princeton 2012) 157-173; and The European Fairy-Tale Tradition: Between Orality and Literacy, ed. Dan Ben-Amos, Spec. issue of Journal of American Folklore 123.490 (2010), which contains a number of dialogic essays.
} 
because the fairy tale as self-conscious genre only came to be during the sixteenth and mostly late seventeenth century, at the hands of authors such as the ones mentioned above, as a result of intertextual, interdiscursive, and intergeneric refashionings that would be continued throughout the centuries. So with the Latin "fairy tale" we find ourselves in the genre's prehistory: texts that are related to it either by analogy or genealogical relationships to specific, "proper" fairy-tale texts. ${ }^{3}$ Historically, these texts have often failed to interest the academic community, because they were deemed "too unclassical for medieval Latin philologists, too recherché (and too Latin) for folklorists and fairy tale scholars." ${ }^{4}$ Where the latter group was only marginally aware of these texts' existence as early (in several cases: the earliest) "attestations" to certain tale types, the former superficially adopted the age old reflex; plainly put, if it looks like a fairy tale, then it must have been a folktale. Even Jan Ziolkowski's recent book, Fairy Tales from Before Fairy Tales: The Medieval Latin Past of Wonderful Lies (2007), while erudite and broad in scope, maintains the basic tenet that its corpus of Latin "fairy tales" was "influenced by or even inspired by oral tales that have perished but that can be recovered by reading or, rather, listening between the lines of the text." I shall revisit one of the texts also discussed by Ziolkowski: the late twelfth- to early thirteenth-century Latin poem Asinarius, which tells of a prince born in the shape of an ass who eventually gains his (physical) humanity through marriage. After presenting the text itself, I offer a brief characterization of traditional perspectives that have dealt with it in terms of folklore and mythology. Opting for a literary contextualization myself, I lay bare a formative intertextual dialogue with the Latin literary tradition, hitherto unexplored, that recasts it as a parodic mock epic.

\section{Asinarids: Fairy Tale, Folktale, Myth?}

The Asinarius is a narrative poem in elegiac distichs, about 400 verses long. Its style and use of language is relatively classical, pleasantly clear and straightforward. ${ }^{6}$ Going on its prosodic, stylistic and thematic features, we could cautiously date its composition around 1200, with a terminus ante quam around 1280, when it was listed in master Hugo von Trimberg's Registrum multorum auctorum (Register of Many Authors) as a much-read classroom text. ${ }^{7}$ Though it is usually thought to come from southern

\footnotetext{
${ }^{3}$ I use the word "proper" loosely here, as the genre and its constituent texts are extremely protean in nature. While Basile's 17th-c. Neapolitan fiabe may have clear thematic connections with some of the Märchen of the Brothers Grimm, to heap them together as if they were the same sort of text would be oversimplifying the matter.

${ }^{4}$ Jan Ziolkowski, Fairy Tales from before Fairy Tales: The Medieval Latin Past of Wonderful Lies (Michigan 2007) 2

${ }^{5}$ Ibid. 5

${ }^{6}$ Aesthetic appreciations of medieval Latin literature have varied throughout the centuries. In the 1865 volume of the grand Histoire Littéraire de la France, Le Clerc concedes that "si le faible auteur de l'Asinarius a du moins quelque valeur pour nous comme le témoin d'une antique tradition littéraire, la poésie latine ecclésiastique n'a rien qui la relève à nos yeux de l'abaissement où elle était tombée" ("if the feeble author of the Asinarius holds at least some value to us as a witness to an ancient literary tradition, the ecclesiastical Latin poetry [of the time] has nothing to show us but the degeneracy into which it had fallen"). V. Le Clerc, "Poésie latine," Histoire Littéraire de la France. Quattorzième Siècle, vol. 24, ed. Académie des Inscriptions et des Belles-Lettres (Nendeln/Liechtenstein 1971) 432-433.

${ }^{7}$ See Karl Langosch, ed., Asinarius und Rapularius (Heidelberg 1929) iv, 14; and Ziolkowski, Fairy Tales (n. 4 above) 204-205.
} 
Germany (mostly on account of manuscript distribution), ${ }^{8}$ its style and content also make it akin to the cultural environment of scholastic France. About the author we know next to nothing, but it is safe to say he enjoyed a classical Latinate education and was most likely male. Given the overtly courtly atmosphere of his poem, we might also assume he had access to higher circles. Meanwhile, we should not exclude the possibility that his knowledge of courtly decorum and entertainments could have easily come from reading courtly literature in Latin and/or the vernacular languages. As for his poem's intended public, we again have several options, not necessarily mutually exclusive. First of all, as we know from Hugo von Trimberg, the Asinarius was read in schools, though that does not necessarily imply that it was written for school use. $^{9}$ A text like this could very well have been created in a playful manner among Latin students or magistri, originally intended to be read by/to a small clique of peers, but eventually winding up in the educational curriculum. Again, given its courtly character and princely protagonist we also have to take into account courtly circles, even considering the possibility that it was written as a speculum principum (mirror for princes) to instruct and amuse some of the crowned heads of Europe. Finally, we could expand the poem's readership to the literate clergy, that most typical breed of Latin readers, who would certainly not have shunned literary genres of a more profane nature. As for the material text, the Asinarius has survived in fourteen extant manuscripts and we know of at least four others now lost to us, mostly from a French, German or Italian provenance. ${ }^{10}$

The story of the poem is as follows: "Once there lived a king of an unknown region and city, but the name of that King no page will tell. He had chosen a consort to rule with and a companion for his bed, equal to him in nobility."11 Unfortunately, the couple cannot conceive an heir to the throne. The Queen prays to the gods until she finally finds herself with child. However, when the infant is born, it becomes apparent that he is actually a little donkey. While the Queen wishes to have the newborn killed, the King deems him a worthy successor and has him raised as such. He grows up to be-

\footnotetext{
${ }^{8}$ See Langosch (n. 7 above) 13-14; and Simona Rizzardi, "Notizie introdutive," Commedie latine del XII e XIII secolo, vol. 5 (Genova 1983) 157-161.

${ }^{9}$ Ziolkowski, Fairy Tales (n. 4 above) 208, believes that, because of its patriarchal, misogynistic and bawdy character, combined with its depiction of male adolescent struggles, the poem would have been more likely "written for an all-male school setting, rather than a mixed courtly audience." Bottigheimer, Fairy Tales (n. 2 above) 100, seems to take her cue from him in claiming that the Asinarius is "a purpose-built abbreviation of a longer romance for a Latin schoolbook, its brevity a schoolroom artifact," a claim which, as far as I can see, goes unsubstantiated. Yet in a later article she argues against its scholastic character, deeming its content lacking "d'une part les références explicites à l'enfance des lecteurs et d'autre part la prescription d'obéissance envers les plus âgés et les meilleurs que soi" ("on the one hand explicit references to the readers' puerility, on the other prescriptions of obedience towards their elders and betters"); Ruth Bottigheimer, "Les contes médiévaux et les contes de fées modernes," Féeries 7 (2010) 29 n. 19. I do not think either of Ziolkowski or Bottigheimer's arguments are strong enough to limit the poem's scope to, or exclude it from, classroom audiences. While we should not idealize courtly audiences, the Asinarius contains more than enough "moral fiber" to make it edifying, not even taking into account the "male adolescent interests" proposed by Ziolkowski.

${ }^{10}$ For a description of these manuscripts and a stemma codicum, see Rizzardi, "Notizie introdutive" (n. 8 above) $173-186$.

${ }^{11}$ The opening verses of the poem in translation. For the Latin text, see infra. All translations in this essay are my own. I have opted to adhere closely to the texts' basic denotative meaning, rather than doing justice to their literariness - somewhat ironic in the present context.
} 
come a perfect courtier, commonly referred to as "the Little Lord." Having acquired a taste for lyre music, the Donkey seeks out the instruction of a professional musician. Though the latter initially refuses to teach him on account of the popular wisdom that one should never attempt that which is not in their nature-donkeys are not known for their agile fingers or good singing voices-the Donkey threatens him into it and soon becomes his master's superior. One day, the Donkey is confronted with his reflection in a river, making him realize (only now!) that his future as heir to the throne is far from certain. Fearing to be run out, he decides to flee the realm preemptively with a trusty servant and wanders across the seas until he comes upon another kingdom at the world's edge. Having charmed the palace doorman with his song and lyre playing, he is allowed entrance to a royal banquet, manages to entertain all the guests there, and is eventually seated at the princess's table, with whom he dines in courtly fashion.

The Donkey remains in the citadel for some time and wins over the King's affections, also meriting a good reputation at the court. When the Donkey is moved by homesickness to return to his own land, the King persuades him to stay by giving him his daughter's hand in marriage. After a joyous wedding feast, the couple retreats to their chambers, not knowing that the King, out of curiosity, has placed a servant there to spy on their "nightly games." As soon as the Donkey believes them to be alone, he unexpectedly strips off his hide, revealing a beautiful youth, only to revert to his old form in the morning. When the King comes to visit his daughter, he is somewhat puzzled to hear of her marital bliss. The servant then tells him of the wonders he has seen and advises the King to take a look for himself the ensuing night. As the couple is sleeping, he sneaks into their chambers, takes away the discarded donkey hide and has it burnt in an oven. At dawn, the Donkey panics when he is unable to find his hirsute skin and intends to flee. The King intercepts him and assures him of his place, even bestowing half the kingdom on him. When the old King dies a year later, his son-inlaw, now (nick)named Neoptolemus, inherits everything. On top of that, he also gains his own father's realm, thus becoming King of two kingdoms.

Going by this summary alone, most present day readers would agree that we seem to be dealing with a fairy tale. However, as I noted above, the fairy tale genre is an early-modern phenomenon, reaching a first climax in late seventeenth-century France. What came before are texts that seem akin to fairy tales in retrospect, either through analogy or genealogical relationships, thematically and/or generically. However, we can usually affiliate these texts with other specific, medieval literary genres, some of which are far removed from our modern fairy tale concept. Looking at the Asinarius in terms of the fairy tale tradition, apart from its more general fairy tale-like elements, it does resemble several "proper" fairy tales from the sixteenth century onward, beginning with Straparola's "Re porco" ("King Pig," in his heterogeneous Boccaccian composition Le piacevoli notti/The Pleasant Nights, 1551, 1553). Straparola's story maintains the central idea of an animal prince who is able to strip off his hide once he is happily married, in this case a homicidal swine in search of a bride who is able to stand his squalor. At the end of the seventeenth century, Straparola's fovola was reconfigured as a conte de(s) fees by the French authors Madame d'Aulnoy in "Le prince Marcassin" ("Prince Wild Boar") and Madame de Murat in "Le Roy Porc" ("The Pig King"). Finally, in the Grimms' Kinder- und Hausmärchen (1812-1856) we 
encounter "Hans mein Igel," featuring a bagpipe- playing hedgehog as wedded princeto-be, as well as "Das Eselein," a prose adaptation of the Latin Asinarius, which Jacob Grimm had come across in a manuscript residing in Berlin. ${ }^{12}$ It is because of these later tales that I include Asinarius in the literary fairy tale tradition, though as part of its pre-history.

The Grimms' reaction to their finding of the manuscript would prefigure much of the scholarship in later times. As Ziolkowski puts it: "To the Brothers Grimm, the utility of the Latin poem lay in having preserved an oral Märchen that they sought to recover, like an authentic old house, from beneath the unwanted accretions and alterations of its later owners." 13 In other words, when they found the story of the Asinarius to obliquely resemble their own conception of the Volksmärchen, they inferred that it must have first taken shape in some oral-folkloric tradition. ${ }^{14}$ Later scholars adopted their hypothesis, some of them treating it as confirmed fact. ${ }^{15}$ Based on its analogies to other "Tales of Magic," the tale type supposedly underlying the Asinarius was included in the standard folkloric index and categorization system The Types of International Folktales. Nonetheless, the index's editors were not able to find undeniable

\footnotetext{
${ }^{12}$ An analysis of the precise relationship between all of these texts is beyond the scope of the present essay. For text editions, see Giovan Francesco Straparola, "Favola I [Il re porco]," Le piacevoli notti, vol. 1, ed. Donato Pirovano (Roma 2002) 63-69; Marie-Catherine Le Jumel de Barneville, baronne d' Aulnoy, "Le prince Marcassin," Contes, vol. 2, ed. Jacques Barchilon and Philippe Hourcade (Paris 1998) 429-498; Henriette Julie de Castelnau, comtesse de Murat, "Le roy porc," Histoires sublimes et allégoriques (Paris 1699) 1-65; Jacob Grimm and Wilhelm Grimm, "Hans mein Igel" and "Das Eselein," Kinder und Hausmärchen. Ausgabe letzter Hand mit den Originalanmerkungen der Brüder Grimm, vol. 2, ed. Heinz Rölleke (Stuttgart 2010) 112-117, 240-244.

${ }^{13}$ Ziolkowski, Fairy Tales (n. 4 above) 226. In keeping with the spirit of their collection, these "unwanted accretions" had to be removed or transformed in order to reconstruct the "original" underlying Märchen. This process entailed translation, prosification, abbreviation, stylistic simplification, narrative linearization, the elimination of all "learned" references to antiquity as well as the more overtly erotic passages, the introduction of quaint folkish expressions, the stressing of bourgeois Protestant values, etc., resulting in a pleasant Grimmian fairy tale. Almost 200 years later, Erich Ackerman published a collection of translated medieval "Märchen," including the Asinarius" Erich Ackerman, trans., "Das Eselchen," Märchen des Mittelalters (Köln 2007) 69-76. While the translator admits that his (prose) translation is "leicht gekurzt" ("slightly abbreviated," ibid. 189), he also seems to have adhered to some of the Grimms" other principles in the selection process; not only does he eliminate all of the classical deities mentioned in the Latin text (which given the semi-popularizing character of his book is something which could be argued for), he also de-eroticizes it, leaving out the more bawdy bits (coming off as unnecessarily prudish). For a detailed discussion of the Grimm's reworking of the Asinarius, see Ziolkowski, Fairy Tales (n. 4 above) 225-229. For a more general discussion of their editing approach, see Ute Heidmann, "Le dialogisme intertextuel des contes des Grimms," Féeries 9 (2012) 9-28; and Jack Zipes, The Brothers Grimm: From Enchanted Forests to the Modern World, 2nd rev. ed. (Basingstoke/New York 2003) 29-64.

${ }^{14}$ Within this line of thinking, they remark that "eigentlich müßte nach der Belauschung des geheimnisreichen Zaubers unglück erfolgen, wenigstens Störung des irdischen Glücks" ("the spying on the mysterious magic should actually be followed by sorrow, or at least a disturbance of earthly happiness"). Jacob Grimm and Wilhelm Grimm, Kinder- und Hausmärchen, vol. 3, ed. Heinz Rölleke (Stuttgart 2010) 248, my italics. They also suggest that the Donkey's initial panic after discovering his hide has been removed could be rationalized by looking at "Hans mein Igel," in which the animal-groom is singed as his skin is thrown into the fire (ibid.). Also compare the annotations to the Grimms' collection in Johannes Bolte and Georg Polívka, Anmerkungen zu den Kinder- und Hausmärchen der Brüder Grimm, vol. 3 (Leipzig 1918) 152166; and Hans-Jörg Uther, Handbuch zu den "Kinder- und Hausmärchen" der Brüder Grimm. EntstehungWirkung-Interpretation (Berlin 2008) 302-304.

${ }^{15}$ See Walter Scherf, Lexicon der Zaubermärhen (Stuttgart 1982) 284; and Fritz Wagner, "Asinarius," Enzyklopädie des Märchens. Handwörterbuch zur historischen und vergleichenden Erzählforschung, vol. 1, ed. Kurt Ranke a.o (Berlin 1977) 866.
} 
tale-like texts has displaced interests in the Asinarius poem as a piece of Latin literature? Regardless of whether one supports the idea that the poet had a folkloric and/or mythical tale at his disposal on which to model his basic plot, its responses to and reconfiguration of texts and genres of the Latin tradition should not be ignored.

\section{"PAGINA NULla DOCET"? ASINARIUS AS MOCK EPIC}

As a point of departure, I again turn to Rizzardi, who aligns the Asinarius with the genre of the Latin elegiac comedy. ${ }^{20}$ This genre emerged during the so-called "Twelfth-Century Renaissance" and most of the affiliated texts come from the Loire valley in France, a region known for its highly developed classical schooling and literary experimentations. ${ }^{21}$ Some scholars also believe it knew a second, German-Italian flourishing during the thirteenth century. ${ }^{22}$ The criteria Rizzardi upholds to qualify the Asinarius as an elegiac comedy are its dramatic and dialogic nature, the elegiac distich meter, its use of Ovidian language, and the presence of erotic themes and comically stereotyped servant characters, all of which she carefully demonstrates. Overall, I agree with her argument, also given that she manages to isolate several intertextual echoes from another member of the genre, the anonymous Pamphilus. However, as Elliot explains in her introduction to Seven Medieval Latin Comedies, both the terms "genre" and "comedy" may actually be misleading here, as the corpus consists of a very heterogeneous collection of texts, some of which are true comedies in the dramatic sense (with references to the works of Terence, though comedies in Antiquity would never have been composed in elegiac distichs), while others tend more towards what has been dubbed "Latin fabliaux" (paternal or analogical to the French genre) or, more neutrally: "Latin comic tales"— perhaps the safest umbrella term for this intergeneric, experimental hodgepodge. In the remainder of this essay, I shall propose that in the case of the Asinarius, we can specify this broad designation further towards a more particular brand of literary comedy, namely that of the mock epic.

For this purpose, I briefly define the mock epic as a literary genre in which abstract conventions and concrete texts of the literary epic tradition are parodied, usually to humorous effect. ${ }^{23}$ As such, mock-epic texts are actualizations of a parodic mode of writing and reading. Though roughly maintaining its abstract characteristics, this parodic mode is subject to literary-historical conditions. With regard to the medieval period, Bayless describes literary parody as "an intentionally humorous literary (written) text that achieves its effect by (1) imitating and distorting the distinguishing characteristics of literary genres, styles, authors, or specific texts (textual parody); or (2) imitating, with or without distortion, literary genres, styles, authors or texts while in

\footnotetext{
${ }^{20}$ See Rizzardi, "Notizie introdutive" (n. 8 above) $150-157$.

${ }^{21}$ See the general intro. to the genre in Asisson Goddard Elliot, Seven Medieval Latin comedies (New York 1984) xiii-1xiii.

${ }^{22}$ See Rizzardi, "Notizie introdutive" (n. 8 above) 157-161.

${ }^{23} \mathrm{I}$ have not been able to find any specialized literature dealing with the pre-modern or Latin mock epic in a systematic manner. For a general introduction to mock epic currents from the Renaissance on, see Ritchie Robertson, Mock-Epic Poetry from Pope to Heine (Oxford 2009) 1-70. Sziklay notes that from the 18 th to early 19 th c., the mock epic was clearly represented in most European literatures; László Sziklay, "Les genres en vers dans les littératures de langues Européennes entre les Lumières et le Romantisme," Le tournant du siècle des Lumières 1760-1820: Les genre en vers des Lumières au Romantisme, ed. György M. Vadja (Budapest 1982) 219-224.
} 
addition satirizing or focusing on nonliterary customs, events or persons (social par$o d y) . "{ }^{24}$ Throughout the rest of the book, she brings further nuance to this by arguing that the medieval Latin parody in particular was a "widespread, uncontroversial, and often sophisticated literary form," 25 interfering with a variety of genres both in verse and prose. Her description of it as "uncontroversial" refers to its relatively benign character: as opposed to many of their modern counterparts, medieval Latin parodies (textually and socially oriented) are usually not that mordantly critical of their subjects, taking highly appreciated, well-known texts as their models. ${ }^{26}$ As we shall see, the Asinarius poem fits in nicely with Bayless's description: as a primarily textual parody of epic conventions and texts, its approach is not so much mocking, as playing with them in a sophisticated and humorous game of intertextuality.

As with the elegiac comedy, it is somewhat misleading to speak of the medieval mock epic in terms of a clearly delineated and unified genre unto its own. While no literary text should ever be seen as restricted to just one generic category (abstract and always artificial), but rather as partaking in a dynamic, self-reshaping interaction of literary forces ${ }^{27}$ the parodic mode of the mock epic actually parades generic transgression as the center of its game. As such, it would have been hard for it to grow into a truly institutionalized genre. ${ }^{28}$ The examples we have of it from Latin literature, antiquity to high Middle Ages, are quite diverse with regards to scope, style and parodic emphasis. To name a few: Culex and Moretum (The Mosquito and The Pesto, pseudoVirgil, 1st c. CE); Petronius's poems on the Fall of Troy and the Roman Civil War (Satyrica, 1st c. CE); arguably Waltharius (10th c.); and Jean d'Hauteville's Architrenius $(12$ th c.). One specific branch of the mock epic that comes to mind here is that of the medieval beast epic, comic narrative poems that feature anthropomorphized animals as their protagonist and depict human mores and vices in a mock-epic frame of reference. Examples include the "Altercatio nani et leporis" ("Altercation of the Dwarf and the Hare," 9th c.?), Ecbasis captivi (The Escape of the Prisoner, 11th c.), "De Lombardo et lumaca" ("The Lombard and the Snail"), Nigel of Longchamps's Speculum stultorum (The Mirror of Fools), Ysengrimus and its cousin, the Roman de Renard (all of them 12th c.). ${ }^{29}$ To be clear, I do not consider the Asinarius a beast epic nor to belong to beast literature in general: the donkey protagonist here does not stand for any particular kind of man, first of all because he actually is one beneath his superficial, artificial beastly appearance, and secondly because there is no direct symbolic

\footnotetext{
${ }^{24}$ Martha Bayless, Parody in the Middle Ages: The Latin Tradition (Ann Arbor 1996) 3.

${ }^{25}$ Ibid. 2.

${ }^{26}$ Ibid. $1-17$.

${ }^{27}$ See Ute Heidmann's and Jean-Michel Adam's construction of the concept of généricité in Le texte littéraire: Pour une approche interdisciplinaire. Au coeur des textes 17 (Louvain-la-Neuve 2009) 7-23.

${ }^{28}$ Robertson, (n. 23 above) 5, considers "mock epic" to be "a retrospective genre term which identifies important similarities among contemporaneous texts. It names an "antigenre" He reserves the term for texts that are critical of the epic literary conventions, distinguishing it from mock-heroic poetry which "acknowledges the authority of serious epic by using its devices to ridicule the actions of lowly beings such as the frogs and mice in the Batrachomyomachia" (ibid.). I have not adhered to this distinction (which would put the Asinarius in the latter category), among other things because medieval Latin parody does not really tend to be critical of literary conventions.

${ }^{29}$ For an introduction to medieval Latin beast literature, see for Jan Ziolkowski, Talking Animals: Medieval Latin Beast Poetry, 750-1150 (Philadelphia 1993) 2-14.
} 
connection between his outward form and his personality and behavior. ${ }^{30}$ Nonetheless, texts like these may have also inspired the Asinarius poet. ${ }^{31}$

In order to qualify the Asinarius as a parodic mock epic, we must first establish its epic "voice." Let us take a look at the opening verses: ${ }^{.2}$

Rex erat ignote quondam regionis et urbis

Sed nomen regis pagina nulla docet. ${ }^{33}$

Hic sibi consortem regni thalamique sodalem

Sortitus fuerat nobilitate parem.

Quos licet imperii maiestas alta bearet

Amplaque congeries nobilitaret opum,

Hic tamen adversa parum Lucina negaret

Gratis enim Veneris excoluere iocos.

Hinc dolor, hinc gemitus ambos vexabat,

heredem regni non habuere sui.

Denique regina misero compassa marito

Tali sive pari voce frequenter ait:

"Quid facimus? Nil proficimus: iam vivere tedet

Nocturnisque piget sepe vacasse iocis.

Femina sum misera sterilique simillima terre

Qui sine spe messis semina iacta vorat.

Pertuso sacco iuste me comparo, qui quod

Ore patente capit hoc aliunde vomit.

Heu, quid nobilitas, quid opes, quid gloria regni

Prosunt, heredem si michi fata negant?"

Continuis igitur precibus pia numina pulsans,

Ut mater fiat nocte dieque rogat.

Quod petit assequitur et fit mater sed ... aselli:

Eius enim partus pulcher asellus erat!

O qualis partus, ubi femina gignit asellum!

O res miranda, plus miseranda tamen! ${ }^{34}$

Once there lived a king of an unknown region and city,

but the name of that king no page will tell.

He had chosen a consort to rule with and a companion for his bed, equal to him in nobility.

But even though they were blessed with the great majesty of ruling

\footnotetext{
${ }^{30}$ On the contrary: unlike Reynard the cunning Fox or Burnellus the idiot Ass (Speculum stultorum), the asellus in the Asinarius behaves in a way that is contrary to what popular and proverbial wisdom expects of him-courtly, refined and with a knack for music, rather than coarse, retarded and in need of a muzzleclearly more Prince than Donkey. Nonetheless, Gatti does situate the Asinarius within the wider (elegiac) beast literature tradition; Paolo Gatti, "Elementi favolistici nell'Asinarius e nel Rapularius," La Favolistica Latina in distici elegiaci: Atti del convegno internazionale Assisi 1990, ed. G. Catanzaro and F. Santucci (Assisi 1991) 149-160.

${ }^{31}$ The Asinarius poet obliquely enters into a discussion with the Speculum stultorum, inverting some of its moral messages. See n. 61.

${ }^{32}$ All Latin quotations from the text are based on Asinarius/La commedia dell'asino, Commedie latine del XII e XIII secolo, vol. 5, ed. and trans. Simona Rizzardi (Genova 1983) 194-251. Earlier editions can be found in Bolte and Polívka (n. 14 above) 152-166; Langosch (n. 7 above) 1-45; and Franz Mone, "Asinarius vel Diadema," Anzeiger für Kunde der deutschen Vorzeit 8 (1839) cols. 551-561. Translations include Ackerman (n. 13 above); Prins Asna, eller Saga om en Drottning, som fodde en Asna, och huruledes samma Asna lärde sig spela på Luta, hwarigenom han slutligen blef gift med en rik och underskón Prinsessa (Stockholm 1823); Rizzardi (n. 32 above); and Ziolkowski, Fairy Tales (n. 4 above) 341-350.

${ }^{33}$ In her edition, Rizzardi prefers "fabula" over "pagina"; Rizzardi, Asinarius (n. 32 above) 194.

${ }^{34}$ Ibid. vv. 1-26
} 
and ennobled by an ample pile of riches,

Lucina remained averse to them and denied them a pregnancy,

so they played the Venus-games in vain.

Hence their pain, hence the sighs that vexed them both,

for there was no heir to their realm.

Finally the Queen, moved by compassion for her husband,

frequently spoke as follows:

"What are we to do? Nothing works! I already dread being alive,

and I am weary of occupying myself with nightly play so often.

I am a miserable woman, barren as the earth

that, without hope, devours the seedlings in its furrows.

I rightly compare myself to a punctured sack that

swallows with an open mouth, only to spit it out afterwards.

Alas, what good are nobility, riches and the glory of ruling

if the Fates deny me an heir?"

So with continuous prayer she entreated the pious gods,

asked them day and night to become a mother.

What she asked was granted and she became mother ... of a little donkey.

Yes, her offspring was a handsome little ass!

$O$ what a delivery, when a woman gives birth to a donkey!

O what a wondrous thing, but pitiable even more so!

As I have suggested, the modern reader might be tempted to look at the poem through an anachronistic Grimmian lens, focusing on its supposed fairy tale-like qualities, which appear to us mostly because of retroactive projections. Indeed, the first four lines give the impression of being a perfect poetic equivalent of the Grimms' formulaic rendering "Es lebte einmal ein König und eine Königin." 35 But are they? We should bear in mind that the Asinarius poet envisioned an utterly different type of model reader, ${ }^{36}$ namely one that was well acquainted with the Latin literary tradition. Indeed, medieval authors writing in Latin were prone to enter into a self-conscious intertextual dialogue with their predecessors and contemporaries, especially so in the long twelfth century, during which the practice of literary rewriting truly flourished. ${ }^{37}$

${ }^{35}$ Grimm and Grimm, Kinder- und Housmärchen, vol. 2 (n. 12 above) 240. Before the birth and institutionalization of the fairy tale as genre in early modern times, there does not seem to have been a connection between phrases like "C'era una volta," "Il y était une fois," "Once upon a time," etc. and fairy tale-like stories. The Latin "Erat/ fuit quondam" is used to introduce a wide variety of classical and medieval narratives. Though some of these narratives are meant to be pondered in a "timeless," exemplary context, others are plainly historiographical in nature. See for instance Fehling's notes with regard to the opening of Apuleius's "Cupid and Psyche," "Erant in quadam civitate rex et regina"; Detlev Fehling, Amor und Psyche: Die Schöpfung des Apuleius und ihre Einwirkung auf das Märchen, eine Kritik der romantischen Märchentheorie. Abhandlungen der Geistes- und Sozialwissenschaftlichen Klasse, vol. 9 (Mainz 1977) 79-88. I shall not discuss the possibility of the Asinarius author having known Apuleius's Metamorphoses here. While mainstream scholarship assumes the text was not well known at the time, Carver does discern a vague influence in 12 th-c.y romance literature; Robert H. F. Carver, The Protean Ass: The Metamorphoses of Apuleius from Antiquity to the Renaissance (Oxford 2007) 78.

${ }^{36} \mathrm{My}$ underlying approach here is influenced by Iser's model of the reading process in Wolfgang Iser, "The Reading Process: A Phenomenological Approach," New Literary History 3.2 (1972) 279-299; as well as by Heidmann's work, who has done similar "palimpsestic readings" of the contes of Perrault, in Heidmann and Adam, Texiualité (n. 1 above) 33-152.

${ }^{37}$ The international Latinitas Perennis project has dealt extensively with continuity and intertextual appropriation within the Latin tradition as a whole. See Yanick Maes, Jan Papy, and Wim Verbaal, eds., Latinitas Perennis I: The Continuity of Latin Literature (Boston/Leiden 2007) and Latinitas Perennis II: Appropriation and Latin Literature (Boston/Leiden 2009). For the importance of textual auctoritas and exemplary auctoritates in 12th-c. Latin literature, see Wim Verbaal, "Teste Quintiliano: Jean de Salis- 
Often, their readers would have to be able to pick up on this dialogue for the text to achieve its fullest effect. ${ }^{38}$ This also seems to be the case with the Asinarius, where an anterior knowledge of epic literature is required to appreciate its parodic dimensions.

Merely glancing at these opening verses, one of the first things the parodic model reader will notice (apart from the language in which they are written) is their poetic form, more specifically their meter: the classical elegiac distich. In Roman Latin poetry, the elegiac distich was most commonly associated with elegies, epigrams and love poetry. From Late Antiquity onward, its applicability was further expanded to include a variety of other narrative genres. During the eleventh and twelfth century, the elegiac distich also became standard for epic compositions, even to the point of taking on an equal position alongside the more traditional dactylic hexameter. ${ }^{39}$ Since the first few verses of the Asinarius speak of kings, queens and the troubling adversity of the goddess Lucina (vv. 1-7), it is reasonable to assume that the reader may already begin to harbor epic expectations. Upon closer reading, these expectations are strengthened further, for the opening of the Asinarius seems to revisit another popular Latin poem of that period, plainly epic in nature: the Ylias (or Versus de excidio Troiae / Verses on the Fall of Troy) of Simon Aurea Capra (Chèvre d'Or), canon of the monastery school of Saint-Victor in Paris. ${ }^{40}$ The poem existed in roughly two main versions, as well as many intermediary forms (truncated, retrospectively contaminated, and/or poetically elaborated, also by Simon himself). ${ }^{41}$ The shorter of these versions, around 432 verses, was composed in the first half of the 1150 's, probably at the instigation of Henry I the Liberal, count of Champagne. Also written in elegiac distichs, it offers a summary of the Trojan war and subsequent adventures of Aeneas as we know them from Virgil's Aeneid, beginning with the births of Hector and Paris and ending in the marriage of Aeneas to Lavinia, which would result in the founding of the Roman people.

bury et Quintilien - un exemple de la crise des autorités au XIIe siècle," Quintilien ancien et moderne. Latinitates 3 (Turnhout 2010) 155-170; and Jan Ziolkowski, "Cultures of Authority in the Long Twelfth Century," Journal of English and Germanic Philology 108.4 (2009) 421-448.

${ }^{38}$ See Jan Ziolkowski, "Towards a History of Medieval Latin Literature," Medieval Latin: An Introduction and Bibliographical Guide, ed. F. A. C. Mantello and A. G. Rigg (Washington, DC 1996) 528-529: "The cozy proximity of author, reader, and audience that Medieval Latin literature often assumes differs acutely from the typical experience of these same participants in communicative acts today, and created intimacies that are impossible to replicate at the remove of many centuries. Texts take for granted a common knowledge - of books that the entire audience has read, of experiences that they all have shared, and of people and topical events that they all know - and make allusions and inside jokes that sometimes elude us. In this sense Medieval Latin literature relies upon textual communities in a way far removed of the experience of the average European or American today." While I agree with Ziolkowski that it is impossible to fully replicate the experience of readers in a given medieval textual community, practically and of course epistemologically, we may nonetheless try to reconstruct certain elements of it, in as far as we have access to other materials that may have belonged to that community, in the case of the present essay: other widely read texts. The "model reader" envisioned here is just that: a hypothetical reconstruction supported by likely intertextual ties.

${ }^{39}$ See Sébastien Peyrard, ed., "L'Ilias de Simon Chèvre d'Or. Édition critique et commentaries" (Diss., École nationale des chartes 2007) clxxxiii. This text is as yet unpublished. I thank Francine Mora-Lebrun for sending me a digital version.

${ }^{40}$ For an introduction to the author and his work, see John F. Benton, Culture, Power and Personality in Medieval France, ed. Thomas N. Bisson (London/Rio Grande OH 1991) 22; André Boutémy, "La Geste d'Enée par Simon Chèvre d'Or," Le Moyen Age 45 (1946) 243-246; and Peyrard (n. 39 above) xxv-xxix.

${ }^{41}$ This conclusion regarding the manuscript tradition was convincingly reached by the poem's most recent and accomplished editor, Peyard, (n. 39 above) clxxvii, who opposes previous scholarly opinions. 
The matter of Troy knew a great revival in the late eleventh to thirteenth century; Simon's Ylias is but one of about twenty surviving literary narratives dealing with it that have come to us from this period, both in Latin and the vernacular languages. ${ }^{42} \mathrm{I}$ would suggest that we may also want to consider the Asinarius as playfully partaking in this current, as its seems that our poet has actually rewritten the initial situation of Simon's Ylias, referring even to his vocabulary and turn of phrasing. As a result, the reader of the Asinarius familiar with this intertext is invited to expect the unfolding of a new Trojan epic. Let us compare the opening verses of Simon's Ylias (short version) to those of the Asinarius shown above:

Diviciis, ortu, specie, virtute, triumphis, rex Priamus clara clarus in urbe fuit. Dum rex, dum proceres, dum starent Pergama, Troja et decus et species et caput orbis erat. Rex Hecubam duxit, sociam sibi nobilitate, auspiciis, forma, rebus, amore, throno. Ex hac suscepit natos, erat Hector in illis summus et in bello fulminis instar habens. Plus ferus ille fero, plus pardo plusque leone; sic fuit absque fere plus ferus ille feris. O faustum natis, o faustum conjuge regem, si pariter Paridem non peperisset ei! Non in eo pignus peperit, sed tela, sed ignem, sed sibi, sed Priamo, sed mala cuncta suis.

Hoc pater, hoc genetrix, hoc fratrum cetus et Hector, hoc etiam regni gloria, Troja, ruit.

Hunc Paridem paritura parens per somnia vidit: vidit pro puero se peperisse facem. ${ }^{43}$

Through riches, descent, appearance, virtue and triumphs, King Priam lived famously in his famous city.

For as long as its King, its eminent citizens and citadel stood strong, Troy

was the gem, the sight, and the capital of the world.

The King married Hecuba, his companion in nobility, ruling, character, wealth, affection and the throne.

From her, he received many children: Hector was among them the greatest, who held the fire of war within.

He was most feral, more than a leopard, more than a lion;

yes, he was more feral than the feral beasts.

O blessed through his offspring, o blessed through his wife the King would be, if she had not also borne him Paris!

42 For a brief survey, see Wim Verbaal, "Homer im lateinischen Mittelalter," Homer-Handbuch: Leben-Werk-Wirkung, ed. Antonios Rengakos and Bernhard Zimmermann (Stuttgart 2011) 329-336. Jung notes how all of the Latin poems dealing with the matter of Troy produced in France in the first half of the 12 th $\mathrm{c}$. go back to the classical texts of Virgil, Ovid, and the Ilias latina. During the second half, the purportedly translated "eye-witness" account Historia de Troiae excidio of Dares the Phrygian (4th c.) recaptured the imaginations of authors writing in Latin and the romanz language, resulting in a plethora of verse and prose adaptations and translations, perhaps most famously Benoit de SaintMaure's Roman de Troie from around 1165. See Marc-René Jung, La légende de Troie en France au Moyen Ages (Tübingen 1996) 331-334. For an online survey of high and late medieval Troy texts with references to online editions, see the Méditerranées research website, "La guerre de Troie dans la littérature tardo-latine et medieval."

${ }^{43} \mathrm{I}$ have used the text edition in Peyrard (n. 39 above) 5-28, vv. 1-18. 
Through him, she did not bring forth a legacy, but artillery and fire, and for herself, Priam and their loved-ones, all sorts of woe.

Because of him, his father, his mother, his other brothers and Hector, and even the glory of the realm, Troy itself, have perished.

The mother-to-be saw Paris in a dream,

saw how instead of a son, she had given birth to a torch.

Both poems begin by introducing a king and his city, shrouded by anonymity in the former, most famous in the latter (As. 1-2: "Rex erat ignote quondam regionis et urbis / Sed nomen regis pagina nulla docet" cf. Yl. 2: "rex Priamus clara clarus in urbe fuit"). Each king is married to a deserving, noble wife with whom he lives contently (As. 3-6: "Hic sibi consortem regni thalamique sodalem / Sortitus fuerat nobilitate parem / Quos licet imperii maiestas alta bearet / Amplaque congeries nobilitaret opum" / Yl. 5-6: "Rex Hecubam duxit, sociam sibi nobilitate, / auspiciis, forma, rebus, amore throno"). After a certain amount of time, the royal couples find themselves expecting a child: Hecuba gives birth to Hector, who will later become the warrior champion of the Trojans, feral as the wildest of beasts (Yl. 9-10). Pregnant again at a later time, she receives a prophetic dream in which she sees herself giving birth to a flaming torch, a warning of how her unborn son Paris will bring about the downfall of Troy (Yl. 11-12, 19-20: "O faustum natis, o faustum conjuge regem, / si pariter Paridem non peperisset ei! ... Hunc Paridem paritura parens per somnia vidit: / vidit pro puero se peperisse facem"). As for the Unnamed Queen of the Asinarius, she is also delivered of a son, not particularly feral, but quite beastly: whereas Hecuba merely dreams of producing a flaming torch, the lamentable fruit of her painful labour is an actual donkey (As. 37-40: "Quod petit assequitur et fit mater sed...aselli! / eius enim partus pulcher asellus erat! / O qualis partus, ubi femina gignit asellum! / O res miranda, plus miseranda tamen"). It is here where the reader unexpectedly encounters a barn animal instead of the more classic, tragic prince, that his epic expectations are put under pressure or even deflated. ${ }^{44}$ From this point onward, the poem will maintain a humorous tension between lofty forms and (seemingly) lowly contents, and vice versa. ${ }^{45}$ The reader soon finds himself to be dealing with a parody, built with imposing scraps of Trojan materials, but carrying a humorous cargo inside.

Moving beyond these quoted verses, the respective fathers' reactions to the unlucky birth are divergent, though interrelated through opposition: whereas King Priam gives orders to have the infant Paris killed to avert calamity, the Unnamed King intervenes when his own wife tries to do likewise, arguing that the Donkey is nonetheless of royal blood (Yl. 23-24: "Nam puerum natum pro jussu regis in Idam / servi tollentes ense necare parant" cf. As. 39-40: "Tunc iussu patris nimio nutritur honore / utpote qui regis nobile pignus erat"). ${ }^{46}$ The parallels between both stories now take on more

\footnotetext{
${ }^{44}$ The birth of the ass itself may also have recalled the not-so-comical, mythical story of Pasiphaë, queen of Crete, who was impregnated by a bull and gave birth to the Minotaur. The story was known at least from Ovid's Metamorphoses (VIII vv. 131-137) and Ars amatoria (I vv. 289-326).

${ }^{45}$ Ziolkowski, Talking Animals (n. 29 above) 10: "a mock epic achieves its effect through making much of little and little of much."

${ }^{46}$ Yl: "For by order of the king, the newborn was carried off to mount Ida / by servants who intended to kill him by the sword." Cf. As.: "Then by order of his father, he was raised with plenty of honor, / seeing as he was the noble son of a king."
} 
general proportions: Paris is spared by his would-be executioners, grows up, plays his role of arbiter in the beauty contest between Juno, Athena and Venus, and is received back into the arms of his family. Sometime later, he crosses the sea to Mycene, where he steals his fabled mistress Helen from her husband Menelaus (Yl. 99: "Ergo Paris properat, transit mare: querit amicam"). ${ }^{47}$ Likewise, the Donkey grows up to become a strapping "noblebeast," leaves home to wander the oceans, and falls in love in the palace of a foreign king. Most fittingly, his voyage there (As. 115-122) is presented to the reader in the most epic of phrases and images, densely resounding with the verses of Virgil, Ovid and Statius. ${ }^{48}$

But the story of Paris is not the only epic model our author engages with: as his poem comes to a close, he unexpectedly slips in a little piece of information that opens up another intertextual perspective of the Trojan kind to his reader, mostly in a retroactive manner. His last verses (396-402) read as follows:

His ita partitis nondum rota volvitur anni

Cum rex emeritus occidit ense necis.

Tunque Neoptolomus regni monarcha creatur;

Solus enim regnum vendicat omne sibi.

Idem preterea patris sortitur honorem,

Sicque regit regum rex duo regna duum.

After [the realm] had been divided, the year had not yet completed its cycle, or the old king perished beneath the sword of death.

Then Neoptolemus was created monarch of the realm;

for only he held claim to the entire realm.

On top of that, he also received his father's honor,

and thus as king he reigns over the two realms of two kings.

Only now does the reader learn the Donkey's name-or, no less likely, a jocular nickname given to him by the author in an afterthought: ${ }^{49}$ Neoptolo(/e)mus. Commentators on the poem in medieval and modern times alike have dealt with this in a rather fleeting manner: Rizzardi and Langosch both refer to medieval glosses that explain the

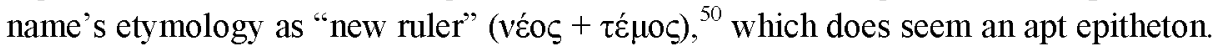
The latter also suggests another possibility, namely that "Neoptolemus" may be understood here metonymically, in the manner it is used in for instance Gautier de Châtillon's Alexandreïs (I, v. 199), where the pair "Neoptolemus/Achilles" stands for "son/father" pars pro toto. With reference to the Asinarius, Langosch pushes it still a bit further to have it mean "son-in-law." 51 Though his train of reasoning does not seem

\footnotetext{
${ }^{47}$ Yl.: "So Paris makes haste: he crosses the sea and finds himself a girlfriend."

${ }^{48}$ See Rizzardi, Asinarius (n. 32 above) 69, 211 n. 118ab.

${ }^{49}$ Both Rizzardi, Asinarius (n. 32 above) 251 n. 399, and Ziolkowski, Fairy Tales (n. 4 above) 220, suggest a parallel here with "The Birth of Vikramāditya," where the enchanted deity's true name is also only revealed in the concluding section, the former even deeming it "proof" of the Latin poem's indebtedness to the Sanskrit tale. Logically, that would have to mean that (1) the postponing of the deity's name is a feature that was present in the version of the Sanskrit tale supposedly at the base of the chain of adaptations (not guaranteed by 14th-c. manuscript versions of the tale), and (2) for some reason that feature would have remained stable throughout all the transfers that would turn it from a Sanskrit myth into a Latin mock epic-something I see no obvious reason for.

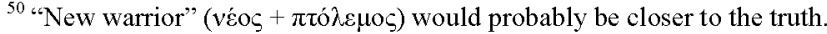

${ }^{51}$ See Langosch (n. 7 above) 45; and Rizzardi, Asinarius (n. 32 above) 251 n. 399.
} 
very convincing to me, he does have one point at least: Neoptolemus is the son of Achilles. Until now, no attempt has been made at exploring a connection between the two namesakes. Yet there are certain grotesque similarities which may elicit a grin from the discerning reader who, ideally, is already on his guard regarding intertextual Trojan ploys.

Though the Asinarius poet may have known about Neoptolemus through any number of popular Troy texts in Latin or vernacular, one source we can be fairly certain of is Virgil's Aeneid, book two of which describes the fall of Troy. There, Neoptolemus is more commonly called by his other name: Pyrrhus. He is one of the few men explicitly named who are concealed within the wooden horse and is most infamous for his brutal murder of King Priam, chillingly recounted by Virgil as follows (II, vv. $547-558):^{52}$

cui Pyrrhus: "referes ergo haec et nuntius ibis

Pelidae genitori; illi mea tristia facta

degeneremque Neoptolemum narrare memento;

nunc morere." hoc dicens altaria ad ipsa trementem

traxit et in multo lapsantem sanguine nati,

implicuitque comam laeva, dextraque coruscum

extulit ac lateri capulo tenus abdidit ensem.

haec finis Priami fatorum; hic exitus illum

sorte tulit, Troiam incensam et prolapsa videntem

Pergama, tot quondam populis terrisque superbum

regnatorem Asiae. iacet ingens litore truncus,

avulsumque umeris caput et sine nomine corpus.

Pyrrhus said [to Priam]: "Then deliver these words and go as my messenger

to my father Achilles; of my sorry deeds

and his degenerate Neoptolemus remember him to tell.

Now die!" And speaking thus, he dragged him to the altar itself, trembling

and slipping over the freshly spilt blood of his son.

He grabbed his hair with his left hand and with the right he pulled out his shiny

sword, then buried it into his side up to the hilt.

This was the end of Priam's fortunes; this undoing

fate did have in store for him, to see Troy aflame, its citadel fallen,

he who once of many peoples and lands had been the proud

Asian ruler. He lies now on the shore, a great trunk,

a head severed from the shoulders, a nameless corpse.

After Priam's slaughter, Pyrrhus ritually sacrifices the dead king's youngest daughter Polyxena on the grave of Achilles, throws Hector's baby son Astyanax from the city walls and takes his widow Andromache for his wife. After his return home, he is eventually killed by Orestes.

What then are the resemblances between our kindly minstrel ass and this cruel kingslayer that would merit him the latter's bloodied name? Beginning on a basic level, the Donkey and Pyrrhus are both princes of royal blood. Both of them cross the

\footnotetext{
${ }^{52}$ I quote from Virgil, Eclogues. Georgics. Aeneid I-VI, trans. H. Rushton Fairclough and G.P. Goold, The Loeb Classical Library 63, ed. Jeffrey Henderson (Cambridge, MA 1999).
} 
sea to arrive at an illustrious foreign city ruled by a great king. ${ }^{53}$ Having first been halted at the gates, both of them are able to infiltrate the palace under the cover of their equine form (a entertainingly musical donkey/a sacrificial wooden horse) and are greeted with glee by the city's inhabitants (a royal banquet and marital festivities/a celebration of the war's end). ${ }^{54}$ As night falls and everybody lies asleep, the Donkey sheds his hide to reveal his true form, while Pyrrhus and his companions are unleashed from their lumber refuge. ${ }^{55}$ Pyrrhus then kills the old king with his sword, something which may be insinuated in the Asinarius through the somewhat unusual choice of words "rex emeritus occidit ense necis" (v. 397) for what the reader would assume to be a natural death from old age ${ }^{56}$ Both princes end up married to the King's daughter (-in-law) - we should note here that in Dares the Phrygian's and Benoît de SainteMaure's influential versions of the story, Andromache is actually counted as Priam's daughter. ${ }^{57}$ Finally, the transformed Donkey inherits the realms and riches of both his own father and those of his father-in-law, while Pyrrhus is able to add his Trojan spoils to the legacy of his dead parent Achilles.

With all this in mind, we may return now to the opening couplet of the Asinarius for a final observation: "Rex erat ignote quondam regionis et urbis / sed nomen regis pagina nulla docet." Not only does it engage with the opening of Simon Aurea Capra's Ylias (cf. supra), I would suggest it also calls back the reader to another couplet in that selfsame poem, where Simon illusively makes mention of some of the major players in the Trojan war: "Eacides qualis fuerit vel quantus et unde, / prodiit, auctorum pagina multa docet." 58 If the Asinarius poet is indeed consciously evoking these verses, we are dealing with a nice bit of irony here, quite in line with the general tone of the poem. For it is exactly here, where he is seemingly disavowing other texts as inspiration for his tale, that he is drawing attention to one text in particular, one that on top of that openly acknowledges literary tradition. ${ }^{59}$ Meanwhile, we have also come

${ }^{53}$ Also see n. 60 .

${ }^{54}$ As regards the quirky idea of the Donkey as a kind of Trojan horse, it is interesting to take a look at medieval and early modern illuminations of the Trojan siege. Whereas the image of a rugged construction of wooden debris has become more popularized, other depictions show a more organically convincing "live" horse. See, for example, BnF MS lat. 7940, fol. 87.

55 There is another passage in Virgil which might have "tickled" the Asinarius author in his likening the Donkey to Neoptolemus, namely Aeneid II, vv. 471-475: "qualis ubi in lucem coluber mala gramina pastus, / frigida sub terra tumidum quem bruma tegebat, / nunc, positis nouus exuuiis nitidusque iuuenta, / lubrica conuoluit sublato pectore terga / arduus ad solem, et linguis micat ore trisulcis."

${ }^{56}$ Browsing through the online image archive of the $\mathrm{BnF}$, one notices how almost every single medieval illumination representing Pyrrhus included there has the sword murder of Priam or sacrifice of Polyxena as its subject. More specifically, they depict the dramatic moment of suspense in Aeneid II, vv. 152-153: "implicuitque comam laeva, dextraque coruscum / extulit ac lateri capulo tenus abdidit ensem." This may suggest that in the medieval (mental) imagery, Pyrrhus was strongly associated with his "sword of death." Perhaps not coincidentally we also find the particular phrasing of the "sword of death" in Simon Aurea Capra's Ylias, where the infant Paris smiles at the blade that is intended to kill him: "at puer aspiciens ensem radiare choruscum/arridet ense nescius ille necis"; Peyrard (n. 39 above) $6 \mathrm{n}$. 25-26. It is possible the Asinarius poet picked it up from there, whether consciously or not.

${ }^{57}$ Benoît's "error" was amended in one later branch of the manuscript tradition; Jung (n. 42 above) 27.

58 "What kind of man Eacus's grandson [Achilles] was, how great and of what parentage / he came, many an author's page does tell." There are slight variations in the manuscript tradition, though "pagina multa docet" mostly remains stable. See Peyrard (n. 39 above) 12 n. 136.

${ }_{59}$ As I mentioned in n. 33, there is a divide in the manuscript tradition of the Asinarius between 
full circle: as the Unnamed King in the opening couplet corresponds to Achilles, so does the Donkey to the latter's son at the close. And so, as the perspective shifts from the story of Paris to that of Pyrrhus, our Trojan Ass changes his grotesque appearance, not from donkey to man, but from Priam's progeny to Priam's killer. ${ }^{60}$

\section{CONCLUSIONS}

I have argued that the adventures of the Donkey Prince are thematically, structurally, and verbally interlaced with those of the ancient princes Paris and Pyrrhus. Considering the Asinarius in relation to the literary tradition of the Latin epic opens up several new perspectives on the poem. First of all, it offers us part of an alternative, more nuanced account of its genesis. Rather than limit the poet's creative effort to the mere embellishment of an existing folktale, we can see how he has actively transformed and recombined elements from a textual tradition quite central to the universe of Latin literature. Secondly, taking into account these epic intertexts, we are confronted with new layers of meaning and effect, otherwise left inactivated, for subsiding in the intertextual dialogue itself. Though the bawdiness and witty textual constructions of the Asinarius already provide the reader with a certain amount of comic relief, its humorous potential is expanded further when the reader is also able to participate in the sophisticated game of intertextual parody that endow it with its mock-epic qualities. But the game does not end here, for there are other intertexts to be taken into consideration; the Asinarius does not only amuse, it also offers an interesting moral twist on medieval proverbial wisdom as portrayed in the literary and visual arts, with donkeys playing lyres, wearing crowns and stubbornly denying their own natural limits. This "Proverbial Ass," however, is another story. ${ }^{61}$

\footnotetext{
"pagina" and "fabula." Rizzardi, Asinarius (n. 32 above) 195 n. 2, opts for "fabula" (with its etymological cal connotation of "to speak"), though she admits her choice to be arbitrary, motivated mainly by her adherence to the notion that the Asinarius is the adaptation of an orally transmitted tale, and that it should better suit its fairy tale-like quality ("carattere favolistico dell'opera"). Ziolkowski, Fairy Tales (n. 4 above) 225 , sees the divide itself as an attestation to the "ambivalence about [the poem's] fundamental orality or literacy ..., caught between the written and the spoken" However, if we accept the hypothesis that the Asinarius is referring here to Simon Aurea Capra's Ylias, "pagina" would be the better reading. I have yet to find another attestation of the phrase "pagina multa/nulla docet."

${ }^{60}$ This may be one of the reasons the introductions to the Donkey's unnamed father and father-in-law are reminiscent of one another. Compare the opening couplet to the verses describing the latter, As. 123124: "Rex quidam regni caput exaltaret ibidem, / Virtutum clarus stemmate, claris avis," "A certain king had raised up high the capital of his realm there, / famous for his virtue and his parentage."

${ }^{61}$ I am referring here to sayings and proverbs such as "asinus ad lyram" ("the ass to the lyre," found in many corners of medieval culture) and "rex illiteratus, asinarus coronatus" ("an unschooled king is a crowned ass," cf. William of Malmesbury and John of Salibury), as well as Nigel of Longchamp's Speculum stultorum. I discuss these intertextual and interdiscursive dialogues at length in "The Latin "Fairy Tale': A Literary Contextualizing Approach" (PhD diss., Ghent 2014).
} 
